\title{
Bioinformatical Analyses of cinnamyl alcohol dehydrogenase (CAD) proteins from higher plant species
}

\author{
Ertuğrul FILİZ ${ }^{1}$, Frat KURT ${ }^{* 2}$ \\ ${ }^{1}$ Duzce University, Cilimli Vocational School, Department of Crop and Animal Production, 81750, Duzce, \\ Turkey \\ ${ }^{2}$ Mus Alparslan University, Faculty of Applied Sciences, Department of Plant Production Technologies, Mus, \\ Turkey
}

\begin{abstract}
Cinnamyl alcohol dehydrogenase (CAD) (EC 1.1.1.195) is an enzyme functioning in the reduction of various phenylpropenyl aldehyde derivatives which are precursors in lignin and lignan production. Species-specific $C A D$ genes have been extensively identified in recent years. In this study, we used bioinformatics tools to characterize and classify plant CADs. The amino acid and nucleotide sequences of 16 CADs from different plant species were used to compare their physiological properties, phylogeny, and conserved motifs. For this purpose, sequence, phylogenetical, structural analyses of proteins were conducted using various servers. All plant CADs had the characteristic alcohol dehydrogenase (PF08240) and zinc-binding dehydrogenase domains (PF00107). According to the physicochemical analysis, it was revealed that the most of plant CADs $(81.25 \%)$ were in acidic character. Sequence length (aa) and molecular weight $(\mathrm{kDa})$ of CAD proteins were found in range of $356-367$ and 38.6-40.5 respectively. The highest sequence similarities were found between Sorghum bicolor and Zea mays (95.3\%), Panicum virgatum and Sorghum bicolor (90.9\%), and Oryza sativa and Zea mays (87.1\%) respectively. Plant $C A D$ s showed divergent exon-intron structures in which exon numbers were ranged from two to six. Four monocot species ( $S$. bicolor, $P$. virgatum, Z. mays, and $O$. sativa) have four exons, whereas Brachypodium distachyon contains only two exons. Phylogenetic analysis revealed that the CAD proteins mainly divided into two groups. The highest bootstrap values were found as follows: Fragaria vesca-Prunus persica clade (100\%), Glycine maxMedicago truncatula (81\%), and S. bicolor-Z. mays (72\%). The 3D structures of plant CADs showed that Oryza and Vitis had the most divergent structures when compared to the other plant species. Eventually, the data represented here contribute to studies aiming at evaluating the plant CADs extensively and at identifying new $C A D$ genes in other plants.
\end{abstract}

Keywords: 3D structure, Cinnamyl alcohol dehydrogenase (CADs), comparative phylogenetics, in silico analysis

\section{Yüksek Bitki Türlerindeki Sinamil alkol dehidrogenaz (CAD) Proteinlerinin Biyoinformatiksel Analizi}

\begin{abstract}
$\ddot{O} z$
Sinamil alkol dehidrogenaz (CAD) (EC 1.1.1.195) lignin ve lignin üretimindeki öncül çeşitli fenil propenil aldehit türevlerinin indirgenmesinde görev alan bir enzimdir. Türlere özgü olan $C A D$ genleri, son yıllarda önemli derecede tanımlanmıştır. $\mathrm{Bu}$ çalışmada $\mathrm{CAD}$ genlerinin (enzim veya proteinlerinin) bioinformatik araçlar kullanılarak karakterize edilip, sınıflandırılması amaçlanmıştır. 16 farklı bitki türünden elde edilen CAD nükleotit ve amino asit dizileri fizyolojik özellikler, filogenetik ve korunmuş motif bölgelerinin karşılaştırılması için kullanılmıştır. $\mathrm{Bu}$ amaçla $\mathrm{CAD}$ proteinlerinin sekans, filojenik ve yapısal analizleri çeşitli sunucular yardımıyla yapılmıştır. Bütün incelenen CAD dizilerinin alkol dehidrogenaz (PF08240) ve çinko bağlayıcı dehidrogenaz domainlerine sahip oldukları gözlenmiştir (PF00107). Fizyokimyasal analiz sonuçlarına göre, CAD’lerin önemli bir kısmının (\%81,25’i) asidik karakterde olduğu gözlenmiştir. Bu proteinlerin amino asit uzunlukları (aa) ve moleküler ağırlıklarının (kDa) $356-367$ ve 38,6-40,5 arasında sırasıyla değişmekte olduğu belirlenmiş̧ir. Dizi benzerlikleri en yüksek Sorghum bicolor ile Zea mays (\%95,3), Panicum virgatum ile Sorghum bicolor (\%90,9) ve Oryza sativa
\end{abstract}

"Sorumlu yazar:f.kurt@alparslan.edu.tr

Geliş Tarihi: 22.09.2018, Kabul Tarihi: 05.02.2019 
ile Zea mays (\% 87,1) arasında bulunmuştur. İncelenen $C A D$ genlerinin intron ve ekzon yapıları birbirlerinden farklılık göstermiş olduğu ve ekzon sayılarının iki ve altı arasında değiştiği belirlenmiştir. Çalışmadaki tek çenekli türler olan S. bicolor, $P$. virgatum, Z. mays, ve $O$. sativa'nın dört ekzona sahip olduğu; Brachypodium distachyon 'un ise sadece iki ekzona sahip olduğu gözlenmiştir. Filogenetik analiz neticesinde CAD proteinlerinin sadece iki ana gruba ayrıldığı saptanmış; en yüksek bootstrap değerleri sırasıyla şu şekilde bulunmuştur: Fragaria vesca-Prunus persica grubu (\%100), Glycine max-Medicago truncatula (\%81), and S. bicolor-Z. mays (\%72). İncelenen CAD'lerin 3 boyutlu analizlerine göre, Oryza ve Vitis CAD'leri, araştırmadaki diğer bitki CAD'lerinden en fazla ayrılma göstermiştir. Son olarak bu çalışmadaki veriler, farklı bitkilerdeki CAD genleri veya proteinlerinin tanımlanması ve değerlendirmesini amaçlayan yeni çalışmalara katkı sağlayacaktır.

Keywords: 3 boyutlu yapı, Sinamil Alkol Dehidrogenaz (CAD’ler), karşılaştırmalı filogenetik, bilgisayar simülasyonlu analiz.

\section{Introduction}

Lignin, the polymer of subunit monolignols, including p-coumaryl, coniferyl, and sinapyl alcohols, is the structural component of cell wall in vascular plants, supporting mechanical resistance against hydrophobicity, plant growth, development, and responses to environmental stresses $[1,2]$. The cinnamyl alcohol dehydrogenase is used in the reduction of cinnamaldehydes into cinnamyl alcohols in the last step of monolignol biosynthesis in the cell wall before oxidative polymerization $[3,4]$.

$C A D$ exhibits different features between gymnosperms and angiosperms. Gymnosperm $C A D$ is encoded by single gene with highly characteristic for coniferyl aldehyde, whereas angiosperm $C A D$ is encoded by multiple genes having crucial affinity for coniferyl and sinapyl aldehydes [5]. The $C A D$ genes display nearly $80 \%$ and $70 \%$ nucleotide sequence identity in all published angiosperm and angiosperms \& gymnosperms sequences [6].

$C A D$ and $C A D$-like genes have been reported in many plant genomes, including Populus trichocarpa, [7] Oryza sativa, [8] Eucalyptus globules, [9] Arabidopsis thaliana [10], wheat [5], sorghum, [11] maize, [12] Picea abies,[13] and Lolium perenne [14]. Nonetheless, in Arabidopsis, 9 $C A D$ genes were identified in $C A D$ multigene families. Among the AtCAD genes, only AtCADl, $A t C A D 4$ and $A t C A D 5$ were found to be related with lignin biosynthesis $[3,15,39]$. The anatomical parts of AtCAD4 and AtCAD5 differs; as AtCAD4 is primarily expressed in leaves and flowers, AtCAD5 expression particularly higher in roots [38]. In the rice genome, 12 distinct genes showed higher similarity to $C A D$ genes [8]. It was reported that AtCAD4 and 5 were phylogenetically grouped in the same clad with bona fide ZmCAD2 (maize), OsCAD2 (rice), SbCAD2 (sorghum) and BdCAD5 (Brachypodium). BdCAD5 and BdCAD3 had similar tertiary structures with AtCAD5; however, in terms of kinetic parameters, BdCAD5 was more involved in lignin biosynthesis [40]. In wheat, a total of 11 wheat $\mathrm{CAD}$ sequences were identified within 6 groups based on the phylogenetic analysis. $T a C A D 1$ is very similar to the other bona fide $C A D$ s in lignin synthesis owing to resemblance of amino acid sequence and three-dimensional structure [5]. As for TaCAD12, it was suggested to involve in plant defense system against Rhizoctonia cerealis [39]. Presence of 15 PoptrCAD genes were reported in poplar [7].

Based on gene structure analysis, three patterns were detected and 14 of the 15 CAD genes distributed on duplicated regions. Also, $C A D$ gene expressions exhibited different patterns. In sorghum, $14 C A D$-like genes at seven different loci were identified. Phylogenetic analysis showed that $S b C A D$ genes clustered into four groups. $S b C A D 2$ groups were similar to bona fide CADs from other species [11]. Jun et al. [41] reported that SbCAD2 and SbCAD4 have high structural and functional resemblance with AtCAD5. Consequently, in this study we performed in silico analysis of cinnamyl alcohol dehydrogenase nucleotide and protein sequences from higher plant species to characterize and classify $C A D$ genes. For this purpose, we also include comparative motif and gene structure, physiochemical, and phylogenetic analyses. 


\section{Materials and methods}

\subsection{Sequence database searches}

CAD protein sequences were collected from NCBI protein database (http://www.ncbi.nlm.nih.gov/protein) by using BLASTP program. The CAD sequences of nine Arabidopsis [15] and 12 Oryza [8] were retrieved from TAIR (http://www.tair.org) and TIGR (http://www.tigr.org), respectively and they were used as queries. The sequences were selected as predicted proteins if their E-value satisfied smaller than $\mathrm{e}^{-10}$. Also, all candidate sequences were analyzed in the Pfam database [16] to detect alcohol dehydrogenase (PF08240) and zinc-binding dehydrogenase (PF00107) domains. Thus, 16 higher plant species (Arabidopsis thaliana, Brachypodium distachyon, Sorghum bicolor, Panicum virgatum, Zea mays, Oryza sativa indica, Solanum lycopersicum, Glycine max, Citrus sinensis, Vitis vinifera, Fragaria vesca, Prunus persica, Cucumis sativus, Ricinus communis, Medicago truncatula, and Populus trichocarpa) were used to analyze CAD protein sequences. The nucleotide sequences of plant CAD proteins were obtained from the Joint Genome Institute (JGI) (http://www.phytozome.net).

\subsection{Prediction of conserved motifs and gene structures of CADs}

Physiochemical data were generated from the Expasy'sProtParam server [17] including sequence length, molecular weight, and theoretical isoelectric point $(p I)$ values. Conserved motifs of CAD proteins were identified by using MEME suite (http://meme.sdsc.edu/meme4_4_0/intro.html) [18]. The following parameters were adopted: the optimum motif width was set to $\geq 6$ and $\leq 50$; the maximum number was set to identify 15 motifs. The sub-cellular distribution and potential $\mathrm{N}$-glycosylation sites of the CAD proteins were predicted by using TargetP 1.1 (http://www.cbs.dtu.dk/services/Target/) [19] and NetNGlyc 1.0 Server (http://www.cbs.dtu.dk/services/NetNGlyc/). A structural figure of CAD genes, including exon and intron numbers, was determined using the Gene Structure Display Server (GSDS) (http://gsds.cbi.pku.edu.cn/) [20]. All CAD protein sequences were aligned with the ClustalW multiple sequence alignment tool. Full protein sequences were taken to display the consensus sequence analysis. Weblogo 3 program was used to compare the conserved motifs of the species [21, 22] .Interacting partners of Arabidopsis CAD and its co-expressed genes were predicted using String 9.1 software (http://string-db.org/) [23].

\subsection{Secondary and tertiary structures analysis}

Secondary and tertiary structures of CAD proteins were predicted by using a web-based tool, PSIPRED v2.5 (http://bioinf.cs.ucl.ac.uk/psipred/) and BioSerf (http://bioinf.cs.ucl.ac.uk/psipred/?bioserf=1) [24, 25]. The tertiary structures of the most divergent CADs were compared to analyze the structural and possible functional differences. Swiss-PdbViewer (DeepView v4.1) program was used to design the CAD protein models (https://swissmodel.expasy.org)[26].The stereochemical qualities of the modeled proteins wereevaluated by RAMPAGE server [27].

\subsection{Phylogenetic analysis}

Amino acid sequences of the CAD proteins were aligned using Clustal W [28]. Phylogenetic analysis were performed by MEGA 5.1 program [29] using a neighbour-joining (NJ) tree method, based on the multiple sequence alignment with following parameters: Poisson correction, pair-wise deletion, and bootstrap analysis with 1000 replicates.

\section{Results and discussion}

\subsection{Physicochemical analysis}

We used totally $16 \mathrm{CAD}$ protein sequences from 16 different plant species for in silico comparative analysis (Table 1). Physicochemical analysis showed that many CAD proteins $(81.25 \%)$ were in acidic 
character $(p I \leq 7)$, while only three proteins belonging to $S$. lycopersicum, G. max, and P. persica had in basic character $(p I \geq 7)$. The average molecular weights and sequence lengths of CADs were calculated as $39.10 \mathrm{kDa}$ and 361 amino acids, respectively. Previous studies are in agreement with our findings, including Cameliasinensis [30], strawberry [31], Eucalyptus globules [9] and Pyrus bretschneideri [38]. Sub-cellular localizations were predicted and only three of 16 CAD proteins were found to be resided in mitochondria (S. bicolor, and Z.mays), and chloroplast (M. truncatula).

$\mathrm{N}$-linked glycosylation cause a basic post-translational modification over proteins with formation of a covalent bounding on asparagine residues owing to oligosaccharide attachment in the polypeptide chains. The N-X-S/T consensus sequence is known as a general recognition element [32]. In our study, nine plants contained putative $\mathrm{N}$ - glycosylation sites (Table 1) suggesting that these sites may regulate protein structures of CADs with relation to various metabolic or physiological conditions. Pfam analyses revealed that all plant CADs had alcohol dehydrogenase GroES-like (PF08240) and zincbinding dehydrogenase domains (PF00107) (Figure 1, Figure 2).

Table 1. Characteristics of CADs in higher plant species, including ORF length, exon and intron number, Pfam family, protein sequence length, molecular weight, predicted subcellular localizations, and $\mathrm{N}$ glycosylation sites.

\begin{tabular}{|c|c|c|c|c|c|c|c|c|c|}
\hline Species & $\begin{array}{l}\text { Accession } \\
\text { Num. }\end{array}$ & $\begin{array}{c}\text { ORF } \\
\text { length } \\
\text { (bp) }\end{array}$ & $\begin{array}{l}\text { Exon } \\
\text { Num. }\end{array}$ & $\begin{array}{l}\text { Pfam } \\
\text { family }\end{array}$ & $\begin{array}{c}\text { Seq. } \\
\text { length } \\
\text { (aa) }\end{array}$ & $\begin{array}{c}\text { M. wt. } \\
\text { (Da) }\end{array}$ & pI & SL & $\begin{array}{c}\mathrm{N}- \\
\text { glycosylation } \\
\text { sites }\end{array}$ \\
\hline $\begin{array}{l}B . \\
\text { distachyon }\end{array}$ & $\begin{array}{l}\text { XP_00358 } \\
1549\end{array}$ & 1098 & 5 & $\begin{array}{l}\text { Alcohol } \\
\text { dehydrogenase }\end{array}$ & 361 & 39.14 & 6.15 & - & $\begin{array}{c}6 \text { NHTQ, } 82 \\
\text { NVST }\end{array}$ \\
\hline S.bicolor & BAJ09366 & 1086 & 2 & $\begin{array}{l}\text { Alcohol } \\
\text { dehydrogenase }\end{array}$ & 365 & 38.65 & 5.84 & M & - \\
\hline$P$. virgatum & ACX50973 & 1098 & 4 & $\begin{array}{l}\text { Alcohol } \\
\text { dehydrogenase }\end{array}$ & 364 & 38.69 & 5.84 & - & - \\
\hline Z. mays & CAA74070 & 1104 & 4 & $\begin{array}{l}\text { Alcohol } \\
\text { dehydrogenase }\end{array}$ & 367 & 38.74 & 5.95 & $\mathrm{M}$ & - \\
\hline O.s. indica & ABB04029 & 1104 & 4 & $\begin{array}{l}\text { Alcohol } \\
\text { dehydrogenase }\end{array}$ & 363 & 38.64 & 5.94 & - & 26 NYTL \\
\hline $\begin{array}{l}\text { S. } \\
\text { lycopersicu } \\
m\end{array}$ & $\begin{array}{l}\text { XP_00423 } \\
3212\end{array}$ & 1092 & 4 & $\begin{array}{l}\text { GroES-like } \\
\text { domain }\end{array}$ & 360 & 39.56 & 8.2 & - & $\begin{array}{c}83 \text { NVSH, } 258 \\
\text { NHSL }\end{array}$ \\
\hline G. $\max$ & AEI54337 & 1083 & 5 & $\begin{array}{l}\text { GroES-like } \\
\text { domain }\end{array}$ & 360 & 39.02 & 7.09 & - & 320 NITA \\
\hline C. sinensis & $\begin{array}{l}\text { ABM6769 } \\
5\end{array}$ & 1083 & 5 & $\begin{array}{l}\text { GroES-like } \\
\text { domain }\end{array}$ & 357 & 38.93 & 5.88 & - & - \\
\hline V. vinifera & $\begin{array}{l}\text { XP_00227 } \\
3147\end{array}$ & 1074 & 5 & $\begin{array}{l}\text { GroES-like } \\
\text { domain }\end{array}$ & 357 & 38.97 & 6.01 & - & 108 NQSL \\
\hline F.vesca & $\begin{array}{l}\text { XP_00429 } \\
1336\end{array}$ & 1074 & 6 & $\begin{array}{l}\text { GroES-like } \\
\text { domain }\end{array}$ & 370 & 40.54 & 6.16 & - & $\begin{array}{c}86 \text { NFSV, } 271 \\
\text { NGTM, } 320 \\
\text { NITC }\end{array}$ \\
\hline P. persica & EMJ23293 & 1122 & 6 & $\begin{array}{l}\text { GroES-like } \\
\text { domain }\end{array}$ & 361 & 39.30 & 7.24 & - & $\begin{array}{c}7 \text { NHTQ, } 271 \\
\text { NGTM, } 320 \\
\text { NITC }\end{array}$ \\
\hline C. sativus & $\begin{array}{l}\text { XP_00416 } \\
6963\end{array}$ & 1086 & 6 & $\begin{array}{l}\text { GroES-like } \\
\text { domain }\end{array}$ & 356 & 39.28 & 5.91 & - & $179 \mathrm{NKSG}$ \\
\hline $\begin{array}{l}R . \\
\text { communis }\end{array}$ & EEF43600 & 1071 & 5 & $\begin{array}{l}\text { GroES-like } \\
\text { domain }\end{array}$ & 357 & 38.84 & 5.75 & - & - \\
\hline A. thaliana & $\begin{array}{l}\text { NP_18857 } \\
6\end{array}$ & 1074 & 5 & $\begin{array}{l}\text { GroES-like } \\
\text { domain }\end{array}$ & 365 & 39.10 & 5.33 & - & - \\
\hline $\begin{array}{l}\text { M. } \\
\text { truncatula }\end{array}$ & AET03358 & 1083 & 5 & $\begin{array}{l}\text { GroES-like } \\
\text { domain }\end{array}$ & 360 & 38.65 & 6.16 & $\mathrm{C}$ & 110 NESL \\
\hline $\begin{array}{l}P . \\
\text { trichocarpa }\end{array}$ & EEE87830 & 1074 & 5 & $\begin{array}{l}\text { GroES-like } \\
\text { domain }\end{array}$ & 357 & 38.96 & 5.76 & - & - \\
\hline
\end{tabular}

M: Mitochondria, C: Chloroplast 


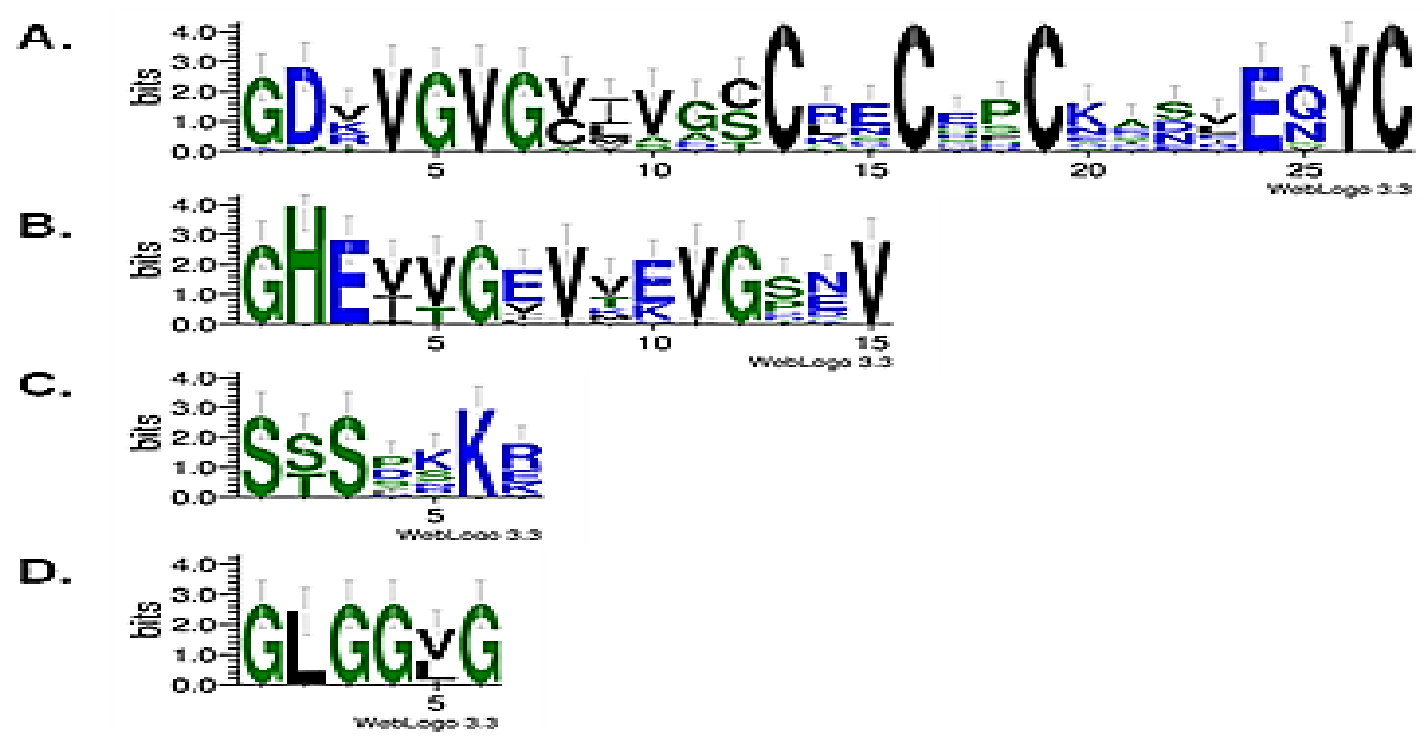

Figure 1. Comparison of critical domains of CAD proteins among 16 plant species. Logo analysis represents Zinc binding domain-Zn2 (A), Zinc binding domain-Zn1 (B), coenzyme specific domain (C), and NADPH binding domain (D).

Citrus
Ricinus
Populus
Sorghum
Zea
Panicum
Oryza
Arabidopsis
Cucmis
Fragaria
Prunus
Solanum
Brachypodium
Glycine
Medicago
Vitis


Citrus
Ricinus
Populus
Sorghum
Zea
Panicum
Oryza
Arabidopsis
Cucumis
Fragaria
Prunus
Solanum
Brachypodium
Glycine
Medicago
Vitis
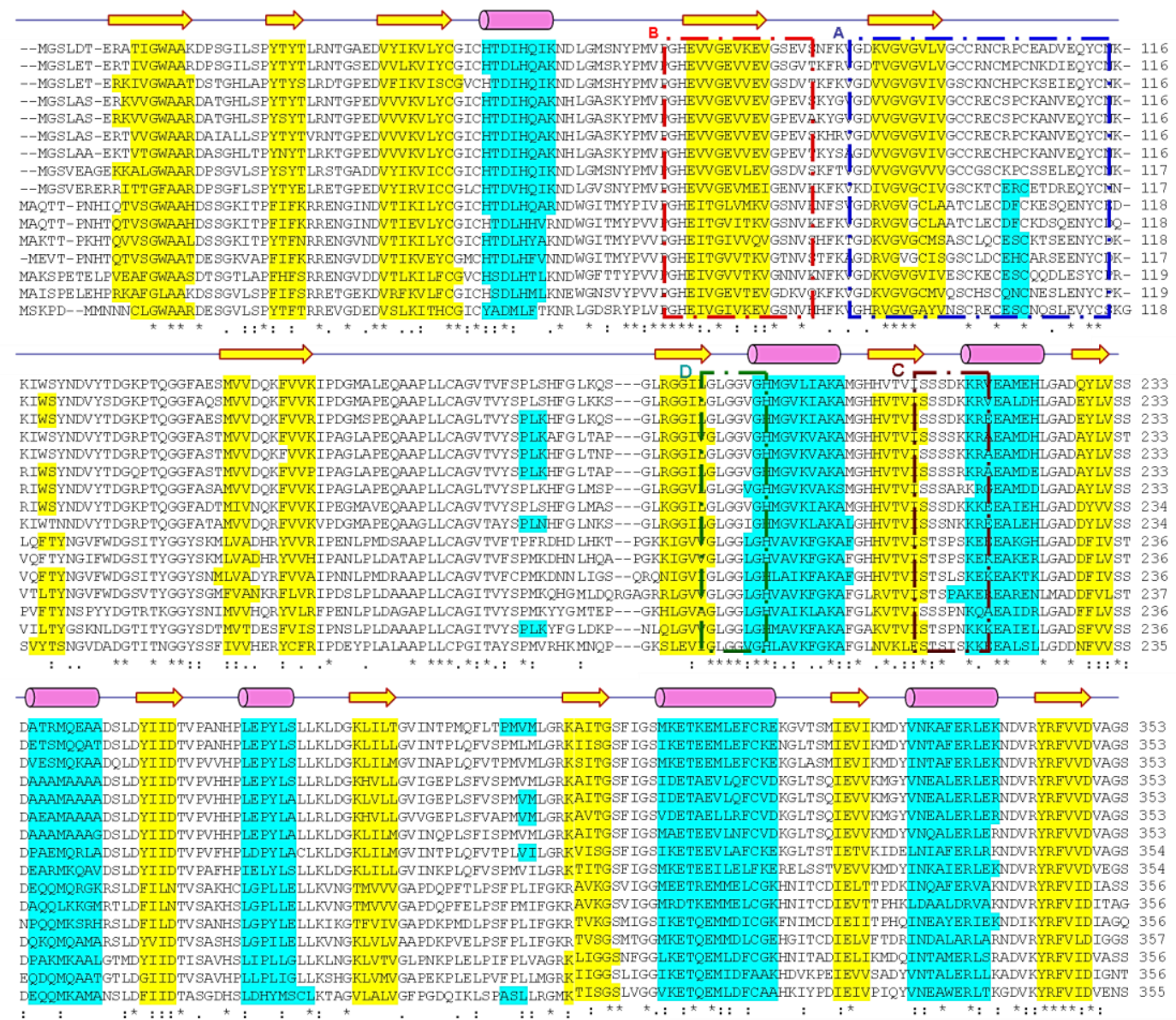

Figure 2. Alignment of $16 \mathrm{CAD}$ proteins belonging to different plant species. Identical residues were labeled with asterisks $(*)$; similar alternate residues with (:); and dissimilar alternate residues with (.). 
$\alpha$-helix and $\beta$-sheet structures were predicted according to PSIPRED program and sequences represent those motifs were labeled with magenta and yellow, respectively. Lines indicated in the upside position shows the predicted loop regions. It gives evident that some CAD proteins' secondary structure differ among others which can affect their three dimensional structures and hence their conformations. Critical domains on CADs were shown into dashed frames: Zinc binding domain-Zn2 (A), Zinc binding domain-Zn1 (B), coenzyme specific domain (C), and NADPH binding domain (D) (Also, for the logo analysis, see in Figure 1).

\subsection{The conserved motifs and sequence divergence of plant CADs}

Conserved motif analysis of 16 plant CADs revealed that a total of 15 motifs were detected (Table 2 and Figure 3). The motif 1, 2, 3, 4, 5, 6, 7, and 9 were observed in all CADs. The motif 10 was only absent in P. persica, while motif 8 was not present in both B. distachyon and S. lycopersicum. The motif 12 (3 members), motif 13 (9 members), and motif 14 ( 2 members) were located in the first position. Interestingly, motif 15 was only observed in Brachypodium and Solanum, whereas motif 14 was only found in Glycine and Medicago. These unique motifs (motif 12, 13, 14, and 15) in CADs may be related to domain binding structures and be specific to these plants.

Based on the sequence identity matrix data (data not shown), the highest identity values were found among the monocot (grass) species; Sorghum, Panicum, Zea, and Oryza. The highest identity was observed between Sorghum-Zea (95.3\%) followed by Panicum-Sorghum (90.9\%), and Oryza-Zea (87.1\%), respectively. It can be thought that $C A D$ genes are well conserved in monocots. Surprisingly, Brachypodium had no higher similarity with the other monocots and this species had the highest identity with Citrus (27.7\%) followed by Arabidopsis (26.8\%), and Vitis (21.8\%), respectively. In the Brachypodium genome, pseudo CAD genes may cause this identity. ArabidopsisCAD (AtCAD4), bona fide $\mathrm{CAD}$, is related to lignin biosynthesis [10] and showed the highest identity with CucumisCAD (70.1\%) suggesting that CucumisCAD gene may take part in lignifications. In dicots, the highest identity value was found between Citrus and Ricinus (86.2\%), followed by Populus-Ricinus (84.8\%), and Prunus-Fragaria $(81.8 \%)$ respectively.

\subsection{Predicted secondary and tertiary structure analysis of plant CADs}

To compare the secondary and tertiary structures of plant CADs, the amino acid sequences were aligned to each other and possible critical domains were shown. Recent reports indicate that CAD proteins are composed of four critical domains: structural zinc binding domain-2 (Zn2), catalytic zinc binding domain-1 (Zn1), coenzyme specific domain, and NADPH binding domain. In this study, fourcritical domains were shown in the secondary and tertiary structure analysis (Figure 1 and Figure 5). NADPH binding domain, comprised of GLGGLG residues in TaCAD12, was reported to bond with pyrophosphate group of NADP [39].

Also, some CAD proteins' secondary structures differ affecting their three dimensional structures and hence their conformations. According to the Ramachandran plot obtained with the RAMPAGE server, $89.1 \%$ and $88.7 \%$ residues in favoured region, $9.2 \%$ and $8.7 \%$ in allowed region, and $1.7 \%$ and $2.6 \%$ in outlier region in Oryza and Vitis, respectively, indicating that the 3D models were reliable and good quality.

It is important to note that the secondary structure of zinc binding domain-Zn2 (Figure 4) was variable among plant CADs. For instance, half of the plant CADs was composed of only single $\beta$-sheet structure while the remaining plant CADs included $\beta$-sheet with an additional $\alpha$-helix structure (Figure 1). Since this domain is very critical for the enzyme activity, the conformational alteration of CAD proteins may affect the enzyme activity positively, or vice versa. Also, in the phylogenetic analysis of CAD proteins, except the $C$. sativus, plants with an additional $\alpha$-helix structure were grouped into the same clade (Figure 8). The similar domain organizations can make the plant CADs functionally identical.

As it was stated in Figure 2, the most divergent CAD genes were found between $O$. sativa and $V$. vinifera. To compare the tertiary structures of those CADs, we modeled their three dimensional configurations (Figure 4A and 4B). It was observed that $V$. vinifera CAD ( $V v \mathrm{CAD}$ ) has a complete $\alpha$ helix (Helix-A) structure between the two main dimeric structures where may serve as a catalytic site. 
Instead, O. sativa (OsCAD) has a fragmented $\alpha$-helix (Helix-A) structure and this critical structural difference may cause functional differentiation between the plant CADs. Also, the models exhibited that an additional $\beta$-sheet structure was resided in the Zn-binding motif of OsCAD protein. However, $V v \mathrm{CAD}$ did not (Figure 5). This may affect the enzyme-substrate interaction and consequently the enzymes' activity. Moreover, six residues (Gly68, His69, Glu70, Gly73, Gly79, and Val82) were found to be interacting with $\mathrm{Zn}$ ion (Figure 5). Although the residues were exactly similar between the $V v \mathrm{CAD}$ and $O s \mathrm{CAD}$, their locations were found to be slightly different that may be the consequence of one-base insertion or deletion in the grapevine CAD protein, or vice versa.

Table 2. The most conserved protein motifs in CAD protein sequences of different plant species

\begin{tabular}{ccl}
\hline Motif & Width & \multicolumn{1}{c}{ Protein sequences } \\
\hline 1 & 50 & PYTYTRRNTGPEDVTIKVLYCGICHTDIHQAKNDWGMSMYPMVPGHEIV \\
2 & 50 & NDVYWDGRPTQGGFASMMVVDQRFVVRIPDNMPPEQAAPLLCAGVTVY \\
3 & 50 & LGGVGHMAVKFAKAMGHHVTVISSSPKKREEAMEHLGADDYLVSSDQQ \\
4 & 50 & GSFIGSMKETQEMLEFCKEHNITCQIEVIKMDYINEAWERLERNDVRYRF \\
5 & 50 & QAAADSLDYIIDTVPAHHPLEPYLSLLKLDGKLILMGVINQPLQFPSPML \\
6 & 36 & NVSKFKVGDRVGVGCIVGCCRECEPCKQNQEQYCNK \\
7 & 15 & RTVFGWAARDPSGHL \\
8 & 15 & HFGLTQPGLRGGILG \\
9 & 8 & MLGRKAIT \\
10 & 8 & VIDVAGSN \\
11 & 6 & EVVEVG \\
12 & 8 & MAQTTPNH \\
13 & 6 & MGSLES \\
14 & 8 & MAKSPETE \\
15 & 8 & QNGMGDQR \\
\hline
\end{tabular}

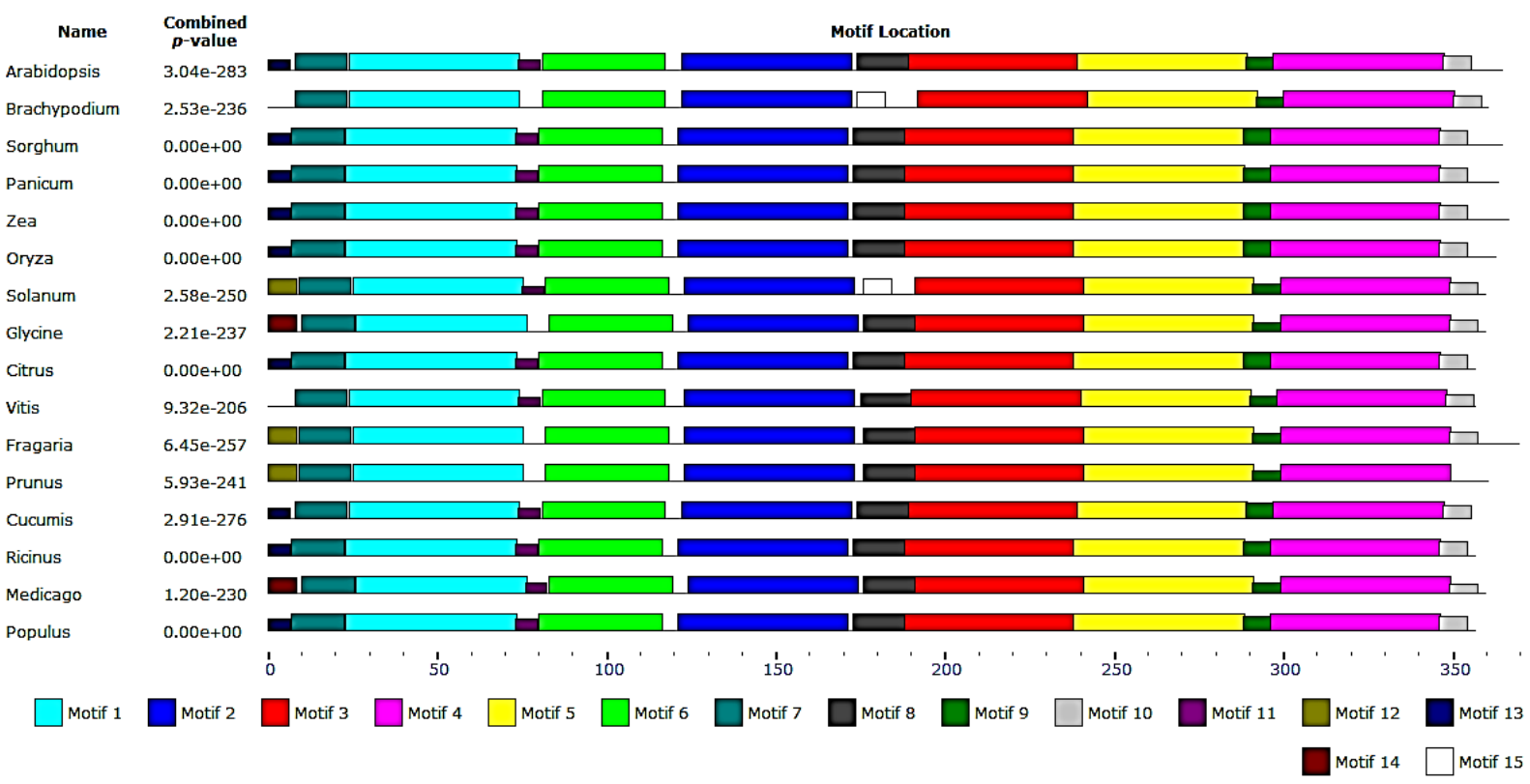

Figure 3. Schematic representation of conserved motifs of plant CADs by MEME server 


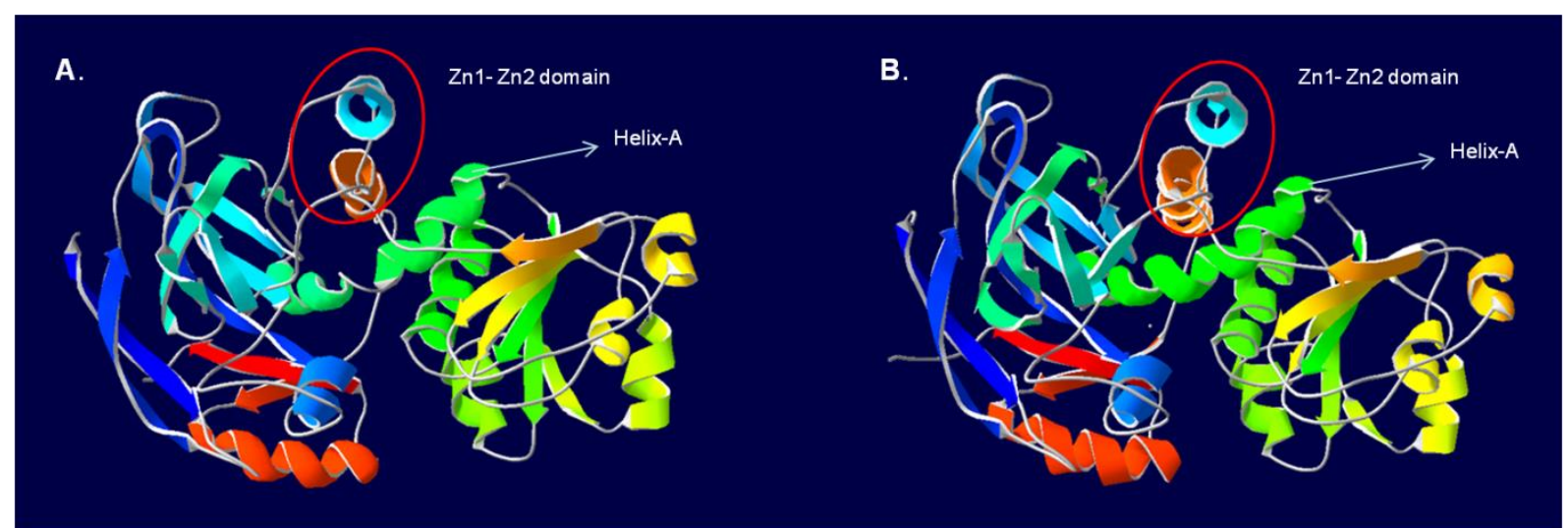

Figure 4. Tertiary structures of CAD proteins in $O$. sativa (A) and $V$. vinifera (B) having the most divergent secondary structures among the 16 CAD proteins. The predicted CAD models were obtained using the BioSerf automated homology and de-novo modeling server. N-terminal (blue) and C-terminal (red) residues were labeled according to rainbow color mode. Also, a partial $\alpha$-helix structure can be clearly observable on $O s C A D$ protein

(A) and a complete $\alpha$-helix (Helix-A) structure in VvCAD

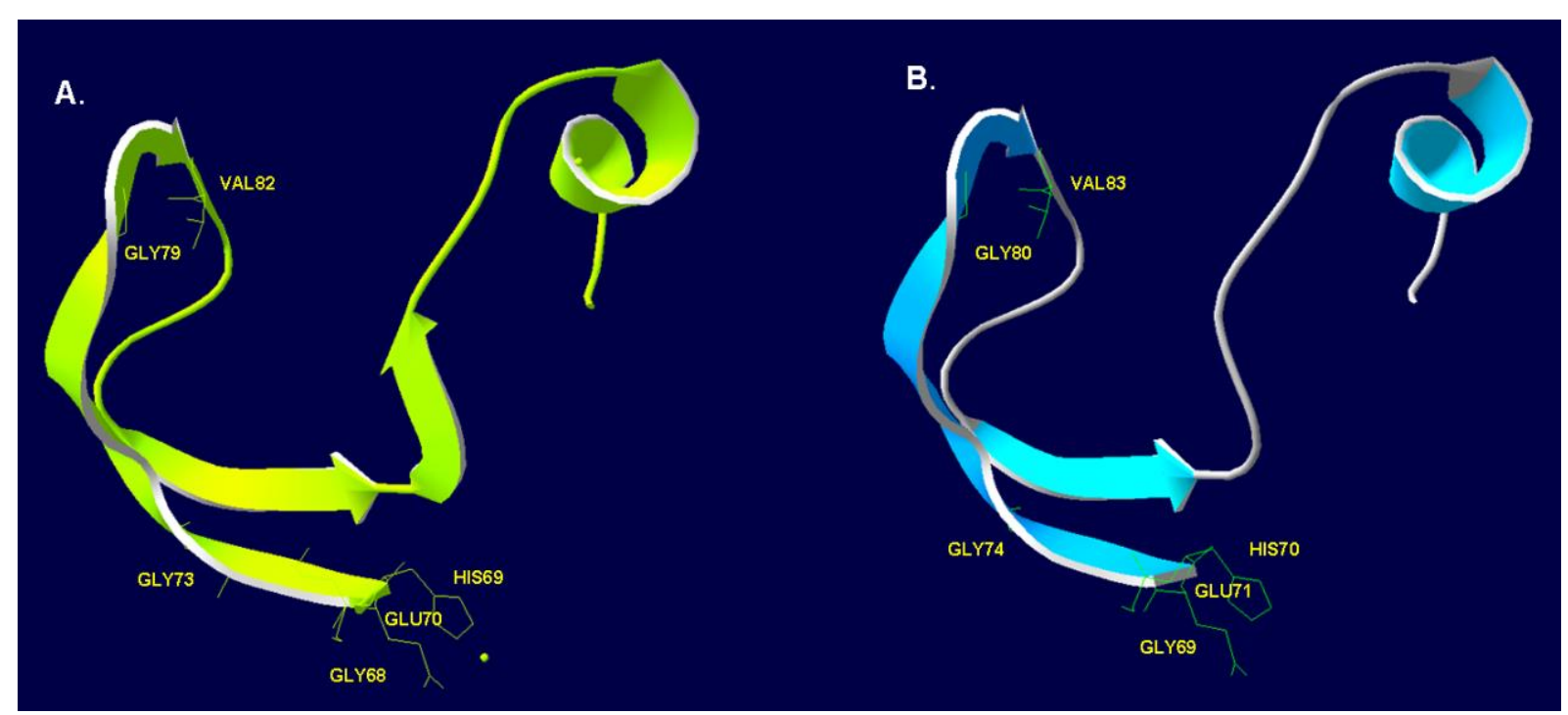

Figure 5. Representation of rice (O. sativa) (A) and grapevine (V. vinifera) (B) Zn-binding motif structures. Prosite patterns of the CAD proteins were searched for the zinc-binding alcohol dehydrogenase enzyme (PS00059) and the corresponding 6 residues interacting with Zn ions were determined (Gly68, His69, Glu70, Gly73, Gly79, and Val82 for OsCAD). Also, it is clearly observable that an additional $\beta$-sheet structure was available in OsCAD motif (A) which may affect the enzyme-substrate interaction and the enzymes' activity

\subsection{The Gene structure and phylogenetic analysis of plant CADs}

The ORF length of plant $C A D$ s were ranged between $1071 \mathrm{bp}$ (C. sativus) and $1122 \mathrm{bp}$ (F. vesca) (Table 1). There were no intronless $C A D$ genes. Exon numbers were varied in range oftwo and six (Figure 6). The exon numbers was found two (one member), four (four members), five (eight members), and six (three members). All monocots had four exons, except Brachypodium (2 exons). Exon-intron structure analysis of $O s C A D$ genes revealed that $O S C A D s$ had two, four, five, and six exons [8]. BrachypodiumCADs were similar to $O s C A D 8 A, B, C$, and $D$ with two exons. In this study, plant CADs exhibited various gene structures with diverse exon-intron numbers. Divergences in exon-intron structure have been observed in duplication events. Structural divergences may generate new protein domain with new biochemical functions [33]. Collectively, CADs in plants may be subjected to gene duplication that causes divergence in their numbers and structures. 


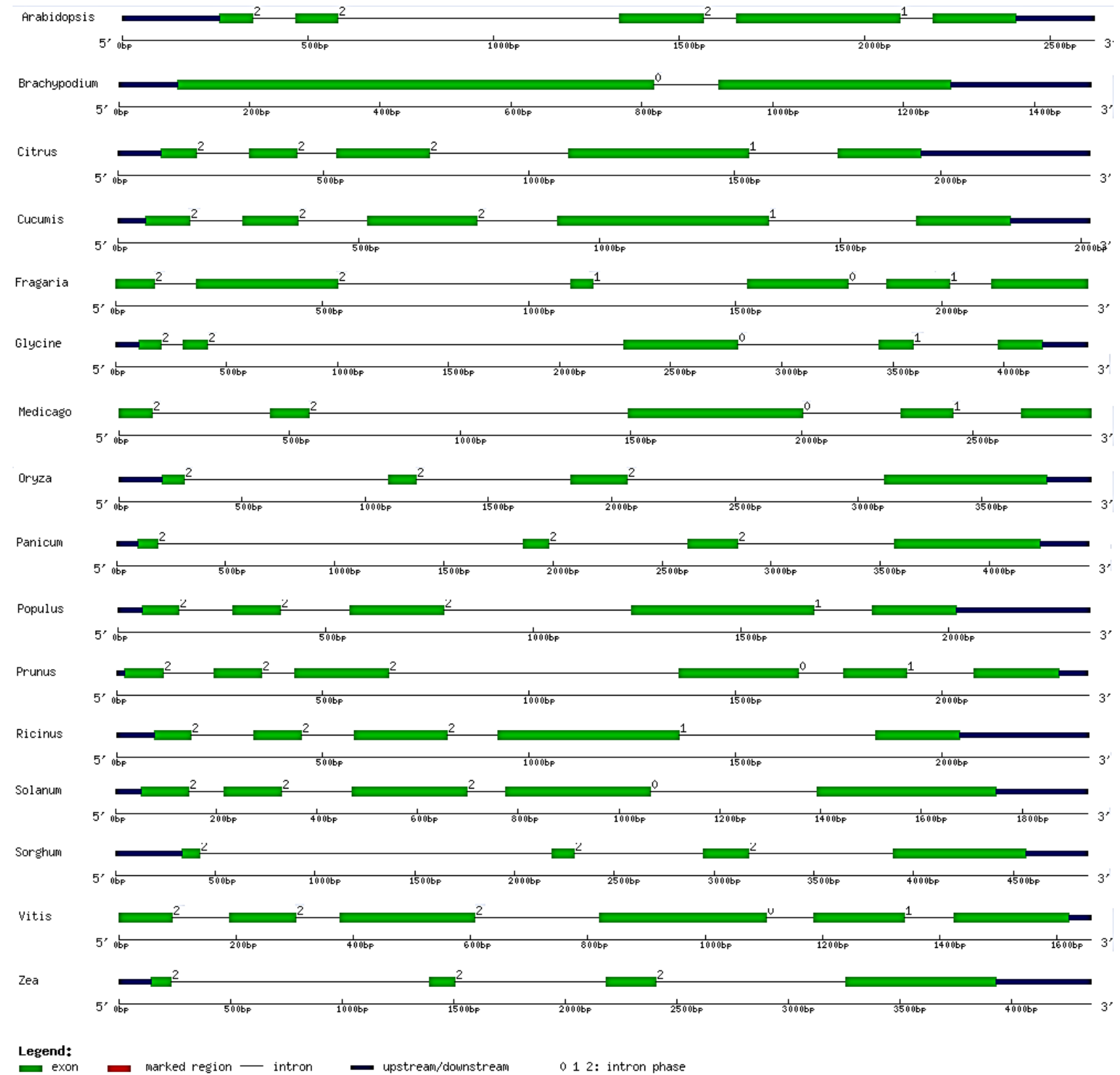

Figure 6. Gene structure of plant $C A D$ genes. Exons and introns are depicted by green filled boxes and single lines, respectively. Intron phases 0,1 and 2 are indicated by numbers 0,1 and 2 in the figure. UTRs are displayed by thick blue lines at the two ends

The interacting partners of Arabidopsis CAD (AtCAD4) was predicted using String server and several annotated proteins were found, including cinnamoyl-coA reductase 1 (CCR1), cytochrome P450, cinnamoyl-coA reductase 2 (CCR2), ferulic acid 5-hydroxylase 1 (FAH1), 3-chloroallyl aldehyde dehydrogenase, UDP-glycosyltransferase, peroxidase 17 (PER17) (Figure 7). Cinnamoyl-CoA reductase is a key enzyme in lignin biosynthesis and the cinnamolyl-CoA esters are converted into monolignols by two enzymes with cinnamoyl-CoA reductase (CCR) and cinnamyl alcohol dehydrogenase (CAD) [34]. Ferulate 5-hydroxylase belongs to cytochrome P450-dependent monooxygenase in phenylpropanoid metabolisms and plays important roles in sinapic acid and syringyl lignin biosynthesis [15]. Peroxidases (class III plant peroxidases, EC 1.11.1.7) are the major enzymes involved in the process of monolignol assembly in lignin biosynthesis [35]. 


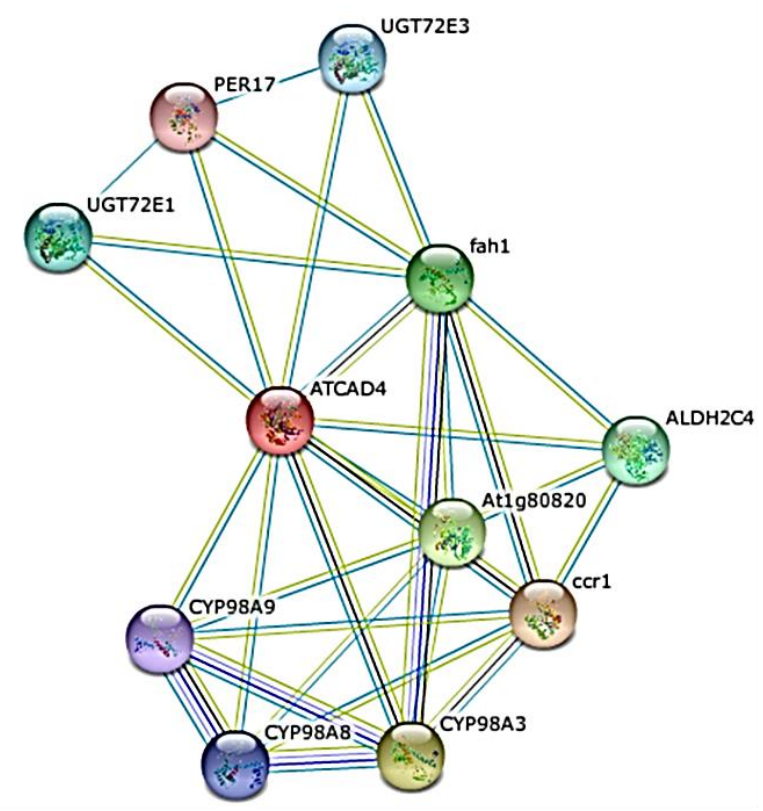

\section{Predicted Functional Partners:}

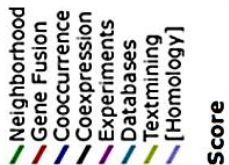

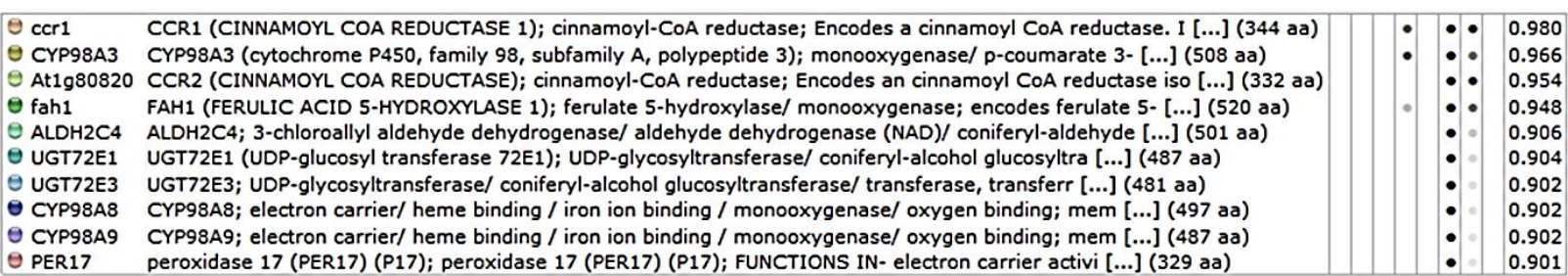

Figure 7. In-silico prediction of interacting partners for CADgene of Arabidopsis by using STRING 9.1. The box shows list with putative interacting partners of barley MoCo sulfurase gene. STRING automatically highlighted the corresponding nodes in the network and the interactions contain direct (physical) and indirect (functional) associations [23]

Phylogenetic analysis of plant CADs revealed that plant CADs were divided into two main groups (Figure 8). The group I had nine species, while group II were composed of seven species. The most of monocots ( 4 of 5 species, except Brachypodium) was belonged to group I. The highest bootstrap value (100\%) was found between Fragaria and Prunus (in Rosaceae family) followed by GlycineMedicago (in Fabaceae family) (81\%) and Sorghum-Zea (in Poaceae family) (72\%). These clades with the highest bootstrap values share the same gene pool due to their belongingness to the same family. Thus, they have similar genetic background and those clades may be related to functional conservation of $C A D$ genes.

It is noteworthy that the monocot Brachypodium clustered in group II with Solanum, Fragaria, and Prunus with the highest bootstrap value (100\%). This close relationship may be related to similar physiological roles. Oryza clustered to Panicum, Zea, and Sorghum clade with the 100\% bootstrap value accordingly. The previous studies showed that the monocot CADs were grouped together [7, 8, 11]. This data is consistent with our findings and it may prove that CADs were conserved well in monocots.

In this study, some sequences from various species grouped close to each other in phylogenetic tree. Gene duplication may play critical role for diversification [36]. The copy number variation and changes in gene family size affects genetic variations among closely related species and individuals [37]. Gene duplication events in CADs may result new catalytic functions that can create similar protein sequences.

In conclusion, $\mathrm{CAD}$ genes play significant role in various metabolic pathways such as lignification, pathogen defense, growth, and abiotic and biotic stress mechanism [39]. Consequently, the results presented here support to understand $C A D$ genes functions in various biological processes in plants and to contribute to in silico and experimental studies about CADs involvement to these processes. 


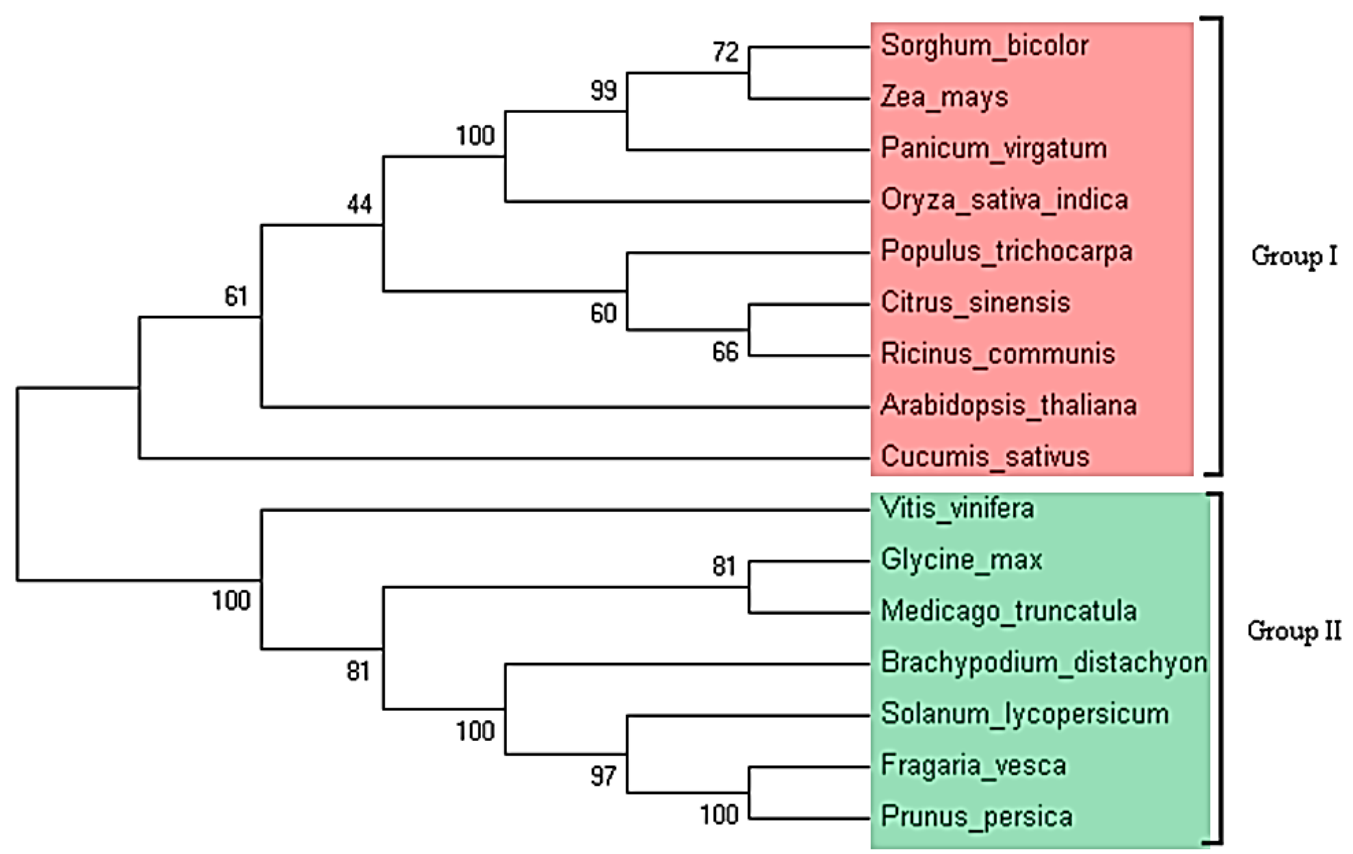

Figure 8. Phylogenetic tree of CAD protein sequences in higher plant species. Sequence alignment was performed using ClustalX and phylogenetic tree was drawn by Neighbour Joining method with MEGA 5.1

\section{References}

[1] Lange B.M., Lapierre C., Sandermann, J.H. 1995 Elicitor-Induced Spruce Stress Lignin. Structural Similarity to Early Developmental Lignins, Plant Physiol., 108: 1277-1287.

[2] Tronchet M., Balagué C, Kroj T., Jouanin L., Roby D. 2010. Cinnamyl Alcohol DehydrogenasesC and D, Key Enzymes In Lignin Biosynthesis, Play An Essential Role In Disease Resistance in Arabidopsis, Molecular Plant Pathology, 11: 83-92.

[3] Sibout R., Eudes A., Mouille G., Pollet B., Lapierre C., Jouanin L., Se'guin A. 2005. Cinnamyl Alcohol Dehydrogenase-C and -D are the Primary Genes Involved in Lignin Biosynthesis in the Floral Stem of Arabidopsis, The Plant Cell, 17: 2059-2076.

[4] Santos W.D., Ferrarese M.L.L., Ferrarese-Filho O. 2006. High Performance Liquid Chromatography Method for the Determination of Cinnamyl Alcohol Dehydrogenase Activity in Soybean Roots, Plant Physiology and Biochemistry, 44: 511-515.

[5] Ma Q.H. 2010. Functional analysis of a Cinnamyl Alcohol Dehydrogenase Involved In Lignin Biosynthesis in Wheat, Journal of Experimental Botany, 61: 2735-2744.

[6] Li X., Ma D., Chen J., Pu G., Ji Y., Lei C., Du Z., Liu B., Ye H., Wang H. 2012. Biochemical Characterization and Identification of a Cinnamyl Alcohol Dehydrogenase from Artemisia annua, Plant Science, 193-194: 85-95.

[7] Barakat A., Bagniewska-Zadworna A., Choi A., Plakkat U., DiLoreto D.S., Yellanki P., Carlson J.E. 2009. The Cinnamyl Alcohol Dehydrogenase Gene Family In Populus: Phylogeny, Organization, and Expression, BMC Plant Biology, 9: 26.

[8] Tobias C.M., Chow E.K. 2005. Structure of the cinnamyl-alcohol dehydrogenase gene family in rice and promoter activity of a member associated with lignification. Planta, 220: 678-688.

[9] De Melis L.E., Whiteman P.H., Stevenson T.W. 1999. Isolation and characterisation of a cDNA clone encoding cinnamyl alcohol dehydrogenase in Eucalyptus globulus Labill. Plant Science, 143: 173-182.

[10] Kim S.J., Kim M.R., Bedgar D.L., Moinuddin S.G.A., Cardenas C.L., Davin L.B., Kang C., Lewis N.G. 2004. Functional reclassification of the putative cinnamyl alcohol dehydrogenase multigene family in Arabidopsis. PNAS, 101: 1455-1460. 
[11] Saballos A., Ejeta G., Sanchez E., Kang C., Vermerris W. 2009. A Genome-Wide Analysis of the Cinnamyl Alcohol Dehydrogenase Family in Sorghum [Sorghum bicolor (L.) Moench] identifies SbCAD2 as the Brown midrib6 Gene. Genetics, 181:783-795.

[12] Halpin C.K., Holt J., Chojecki D., Oliver B., Chabbert B., Monties B., Edwards K., Barakate A., Foxon G.A. 1998. Brown-midribmaize (bm1): A Mutation Affecting the Cinnamyl Alcohol Dehydrogenase Gene, Plant J., 14: 545-553.

[13] Schubert R., Sperisen C., Müller-Starck G. La Scala S., Ernst D., Sandermann Jr. H., Hager K.P. 1998. The Cinnamyl Alcohol Dehydrogenase Gene Structure in Picea abies (L.) Karst.: Genomic Sequences, Southern Hybridization, Genetic Analysis and Phylogenetic Relationships, Trees, 12: 453-463.

[14] Lynch D., Lidgett A., McInnes R., Huxley H., Jones E., Mahoney N., Spangenberg G. 2002. Isolation and Characterisation of Three Cinnamyl Alcohol Dehydrogenase Homologue cDNAs from Perennial Ryegrass (Lolium perenne L.). J. Plant Physiol, 159: 653-660.

[15] Kim Y.J., Kim D.G., Lee S.H., Lee I. 2006. Wound-Induced Expression of the ferulate 5hydroxylase gene in Camptotheca acuminate. Biochimica et Biophysica Acta, 1760: 182-190.

[16] Sonnhammer E.L., Eddy S.R., Durbin R. 1997. Pfam: A Comprehensive Database of Protein Domain Families Based on Seed Alignments. Proteins, 28: 405-420.

[17] Gasteiger E. 2005. Protein Identification and Analysis Tools on the ExPASy Server. In: John M. Walker ed, The Proteomics Protocols Handbook, Humana Press, 571-607.

[18] Timothy L., Mikael Bodén B.., Buske FA., Frith M., Grant C.E., Clementi L., Ren J., Li W.W., Noble W.S. 2009. MEME SUITE: Tools for Motif Discovery and Searching, Nucleic Acids Research, 37: 202-208.

[19] Emanuelsson O., Nielsen H., Brunak S., Heijne G. 2000. Predicting Subcellular Localization of Proteins Based on Their N-Terminal Amino Acid Sequence. J. Mol. Biol., 300: 1005-1016.

[20] Guo A.Y., Zhu Q.H., Chen X., Luo J.C. 2007. GSDS: A Gene Structure Display Server. Yi Chuan $29(8): 1023-1026$.

[21] Schneider T.D., Stephens R.M. 1990. Sequence Logos: A New Way to Display Consensus Sequences. Nucleic Acids Res., 18: 6097-6100.

[22] Crooks G.E., Hon G., Chandonia J.M., Brenner S.E. 2004. WebLogo: A sequence logo Generator. Genome Research, 14: 1188-1190.

[23] Franceschini A., Szklarczyk D., Frankild S., Kuhn M., Simonovic M., Roth A., Lin J., Minguez P., Bork P., von Mering C., Jensen L.J., 2013. STRING V9.1: Protein-Protein Interaction Networks, with Increased Coverage and Integration, Nuc Acid Res 41: 1. doi-10.1093/nar/gks1094.

[24] McGuffin L.J., Bryson K., Jones D.T. 2000. The PSIPRED Protein Structure Prediction Server. Bioinformatics, 16 (4): 404-405.

[25] Buchan D.W., Ward S.M., Lobley A.E., Nugent T.C., Bryson K., Jones D.T. 2010. Protein Annotation and Modelling Servers at University College London, Nucl. Acids Res., 38 Suppl, W563-W568.

[26] Guex N., Peitsch M.C., Schwede T. 2009. Automated Comparative Protein Structure Modeling with SWISS-MODEL and Swiss-PdbViewer: A historical perspective, Electrophoresis, 30: S162S173.

[27] Lovell S.C., Davis I.W., Arendallp W.B. 3rd, de Bakker P.I., Word J.M., Prisant M.G., Richardson J.S., Richardson D.C. 2003. Structure Validation by C $\alpha$ Geometry: $\varphi$, $\psi$ and C $\beta$ Deviation, Proteins, 50: 437-450.

[28] Thompson J.D., Higgins D.G., Gibson T.J. 1994. CLUSTAL W: Improving the Sensitivity of Progressive Multiple Sequence Alignment Through Sequence Weighting, Position-Specific Gap Penalties and Weight Matrix Choice. Nucleic Acids Res, 22:4673-4680.

[29] Tamura K., Peterson D., Peterson N., Stecher G., Nei M., Kumar S. 2011. MEGA5: Molecular Evolutionary Genetics Analysis Using Maximum Likelihood, Evolutionary Distance, and Maximum Parsimony Methods. Molecular Biology and Evolution, 28: 2731-2739.

[30] Deng W.W., Zhang M., Wu J.Q., Jiang Z.Z., Tang L., Li Y.Y., Wei C.L., Jiang C.J., Wan X.C. 2013. Molecular Cloning, Functional Analysis of Three Cinnamyl Alcohol Dehydrogenase (CAD) Genes in The Leaves of Tea Plant, Camellia sinensis. Journal of Plant Physiology, 170: 272-282.

[31] Blanco-Portales R., Medina-Escobar N., Lopez-Raez J.A., Gonzalez-Reyes J.A., Villalba J.M., Moyano E, Caballero J.L., Munoz-Blanco J. 2002. Clone, Expression and Immunolocalization 
Pattern of a Cinnamyl Dehydrogenase Gene from Strawberry (Fragaria ananassa cv. Chandler), J Exp Bot., 375:1723-34.

[32] Schwarz F., Aebi M. 2011. Mechanisms and Principles of N-Linked Protein Glycosylation. Current Opinion in Structural Biology, 21: 576-582.

[33] Xu G., Guo C., Shan H., Kong H. 2011. Divergence of Duplicate Genes in Exon-Intron Structure. PNAS, doi/10.1073/pnas.1109047109.

[34] Boerjan W., Ralph J., Baucher M. 2003. Lignin Biosynthesis, Annu Rev Plant Biol., 54: 519-46.

[35] Herrero J., Esteban-Carrasco A., Zapata J.M. 2013. Looking for Arabidopsis thaliana Peroxidases Involved in Lignin Biosynthesis. Plant Physiol. Bioch., 67: 77-86.

[36] Lawton-Rauh A. 2003. Evolutionary Dynamics of Duplicated Genes in Plants. Molecular Phylogenetics and Evolution, 29: 396-409.

[37] Lynch M. 2007. The Origins of Genome Architecture. Sinnauer, Sunderland.

[38] Cheng X., Li M., Li D., Zhang J., Jin Q., Sheng L., Cai Y., Lin Y. 2017. Characterization and Analysis of CCR and CAD Gene Families at the Whole-Genome Level for Lignin Synthesis of Stone Cells in Pear (Pyrus bretschneideri) Fruit, Biology open, 6 (11): 1602-1613.

[39] Rong W., Luo M., Shan T., Wei X., Du L., Xu H., Zhang Z. 2016. A Wheat Cinnamyl Alcohol Dehydrogenase TaCAD12 Contributes to Host Resistance to the Sharp Eyespot Disease. Frontiers in Plant Science, 7: 1723.

[40] Bukh C., Nord-Larsen P.H., Rasmussen S.K. 2012. Phylogeny and Structure of the Cinnamyl Alcohol Dehydrogenase Gene family in Brachypodium distachyon. J Exp Bot., 63 (17): 6223-36.

[41] Jun S.Y., Walker A.M., Kim H., Ralph J., Vererris W., Sattler S.E., Kang C. 2017. The Enzyme Activity and Substrate Specificity of Two Major Cinnamyl Alcohol Dehydrogenases in Sorghum (Sorghum bicolor), SbCAD2 and SbCAD4. Plant Physiol., 174 (4): 2128-2145. 